\title{
THE GENESIS OF THE INTERNATIONAL CRIMINAL COURT
}

\author{
Oleksandra Huzik* \\ Institute of Law of Taras Shevchenko National University of Kyiv, Ukraine, E - mail: \\ oleksandra.guzik@gmail.com
}

(Received: August 2021; Accepted: October 2021; Published: December 2021)

\begin{abstract}
This work analyzes the practice of the International Criminal Court (ICC) as the most ambitious project aimed at combating and preventing mass violations of human rights in inter-and intrastate conflicts. Sure thing, such an institution has not emerged from anywhere, but it is the culmination in the progress of international criminal law evolution. That is why the progress that was made over the centuries and historical conditions forcing its establishment cannot be ignored. This article studies the formation of the International Criminal Court through the prism of the history of previous models of judicial bodies bringing to justice war criminals. Moreover, it analyses the historical conditions and international debates around the establishment of a permanent international criminal court. Conclusions focus on the problems that arose during the establishment of the ICC, and the ways in which they affect ICC activities nowadays.
\end{abstract}

Keywords: International Criminal Court (ICC); treaty ratification and compliance; international criminal justice; international crimes.

\section{Introduction}

This work analyzes the practice of the International Criminal Court (ICC) as the most ambitious project aimed at combating and preventing mass violations of human rights in inter-and intrastate conflicts. Sure thing, such an institution has not emerged from nowhere, as Dr. Cenap Cakmak put it: "permanent international criminal court is the culmination in the progress of international criminal law evolution". That is why the progress that was made over the centuries and historical conditions forcing its establishment cannot be ignored. This article studies the formation of the International Criminal Court through the prism of the history of previous models of judicial bodies bringing to justice war criminals. Then, it proceeds with an analysis of historical conditions and international debates around the permanent international

*Corresponding author: Oleksandra Huzik.E-mail: oleksandra.guzik@gmail.com

Copyright (C) 2021 The Author(s). Published by VGWU Press

This is an Open Access article distributed under the terms of the Creative Commons BY 4.0 license (Creative Commons - Attribution 4.0 International - CC BY 4.0) which permits unrestricted use, distribution, and reproduction in any medium, provided the original author and source are credited. 
The Genesis of the International Criminal Court

criminal court. In conclusion, it focuses on the problems that arose during the establishment of the ICC, and the way in which they affect ICC activities nowadays.

\section{Historical overview of the activities of international tribunals}

The evolution of international criminal law is suggested to divide into three main periods - that of national, exclusive and universal jurisdiction. The first period can be characterized as the one when international crimes were prosecutable by national jurisdictions alone. The main principle that lay in the rationale for this approach is the principle of territoriality.

Another crucial movement for the rationale for the establishment of ICC is the development of the concept of individual responsibility in light of international law. As we know, traditionally customary and conventional law of war implicated only state responsibility. M. Buromensky, referring to the fact that states are the main subjects of international relations, stated that "the question of responsibility in international law is formulated primarily as a question of the responsibility of states". Accordingly, it is states-violators who were subjects liable to pay reparations or provide other civil remedies to aggrieved nations.

However, given the illegal actions of the state are related to the specific actions of particular individuals, and that in most cases perpetrators remained unpunished, states have agreed that these acts must be included in the scope and domain of international law. As the Nuremberg Military Tribunal put it: "Crimes against international law are committed by people, not abstract categories, and only by punishing individuals who have committed such crimes can the rule of international law be met." Consequently, the issue of the established international organ with exclusive jurisdiction became more and more popular in international legal thought. As early as 1872 Gustave Moynier claimed an international impartial body was needed because of the inability of national judges to make fair decisions about crimes committed in wars in which their states had been involved. At the same time, the tribunal was expected to be the only decision-making body, then it would notify its judgments to interested governments, that shall impose the penalties.

Two years later the Brussels Protocol was one of the first attempts to normalize the behavior of the army during hostilities on land. This was the first treaty that mentioned individual criminal liability for breaches of international humanitarian law. Although this Protocol was signed by 15 European states, it was not ratified. Subsequently, in 1880 few experts in the field of international law prepared a handbook "The Laws of War on Land", which drew attention to the unresolved issue of implementation of the Brussels Protocol and the consequences of violating its norms, in connection with which this guide became the basis for subsequent international treaties. 
Huzik, O., (2021)

The Genesis of the International Criminal Court

Later, 26 states participated in the First International Peace Hague Conference. As the result, the Convention for the Pacific Settlement of Disputes and a Court of Arbitral Justice (PCA) was created. In 1907, during the second conference states adopted 13 conventions on different aspects of warfare. The number of participants also increased up to 44 states, which demonstrates a grown interest in global cooperation for combating war crimes.

Even though enforcement of Conventions was very limited, these documents were used later, forming a basis for international criminal law. For example, these Conventions were referred to in the Nuremberg Judgement, their provisions also appeared in the reports of non-governmental organizations.

The First World War marked a new page in the history of reaction to committed atrocities during wartime. Special Commission on the Responsibility of the Authors of the War and Enforcement and Punishment, created at the conference, reached a conclusion that war criminals should be punished for their inhumane actions. However, an effective mechanism to investigate war crimes was not created.

Although Andreasen characterized World War I as "the true impetus for the creation and acceptance of international jurisdiction over individuals committing war crimes", the interwar period cannot be characterized by any concrete actions toward the establishment of international criminal court. There was a try to form the International Penal Code, however, it was signed by thirteen states.

The next period started right after the end of World War II. On August 8, 1945, in London as a result of a meeting of representatives of the victors of World War II was signed an agreement on the prosecution and punishment of major war criminals of the Nazi bloc. The tribunal was supposed to be temporary, consisting of four judges and four deputies, one from each of the four-member states of the Alliance (the USA, the UK, the USSR and France). In addition, the tribunal had a commission of prosecutors from the same countries to prepare an indictment and present evidence. The Chief Prosecutor was responsible for investigating and prosecuting the main criminals responsible for "crimes against peace", "war crimes" and "crimes against humanity".

Similar powers were subsequently assigned to the International Military Tribunal for the Far East (also called the Tokyo International Tribunal) to resolve the issue of criminal prosecution of the main leading statesmen of Japan. It was established in response to the USSR's request on January 19, 1946. The tribunal had the right to punish mostly Japanese war criminals - its 'leaders, organizers, instigators and accomplices. The distinctive feature of these tribunals was that it was common practice in the Tokyo International Tribunal to prosecute crimes committed against prisoners of war. Another difference laid in that the Tokyo International Tribunal was based on the General's order, instead of a treaty. 
As the result of the proceedings, 28 persons were found guilty, and the majority were charged with life imprisonment. Interestingly, the enforcement of their sentences was subjective, as depended on General MacArthur. His power, in this case, was accurately described as having "the power to grant clemency, reduce sentences, and release convicted war criminals on parole".

To sum up, the most important achievements of the International Military Tribunal for Nuremberg and the International Military Tribunal for the Far East tribunals were that for the first time in the history of international law, international judicial acts condemned aggression as the most serious crime against humanity, severely punishing not only the perpetrators but also the organizers of, particularly serious crimes.

On the other hand, the International Military Tribunal and the Tokyo International Tribunal were military courts created by victorious over the defeated, in other words, they delivered the justice of victorious powers and served their interests. For example, Japan did not have the opportunity to raise the issue of US responsibility for the use of nuclear weapons in Japan. The rules of procedure and proof were developed by the Americans and were based on American law, without embodying the requirements of other states. Moreover, judges were also from the Allied forces. This raised doubts and questions regarding the impartiality of the proceedings. This was the base for the tribunals being strongly criticized.

Yet, given the generally positive results of international tribunals, the UN General Assembly later had taken concrete active steps to establish a permanent court. It instructed the International Law Commission (ILC) to explore the possibility of the court's establishment. As the result, on 11 December 1946, the Assembly passed Resolution "Affirmation of the Principles of International Law Recognised by the Charter of the Nuremberg Tribunal". Finally, in 1950, the ILC adopted a report on the "Principles of International Law Recognised in the Charter of the Nuremberg Tribunal and in the Judgement of the Tribunal"

With the end of the Cold War, the issue of international criminal justice became even more relevant, as the international community faced arbitrary violation of international law through the commitment of the heinous crimes in the territory of former Yugoslavia and Rwanda. In both cases, the United Nations SC established ad hoc tribunals. The UN Security Council adopted Resolution 780, which established a Commission of Experts to investigate atrocities in the former Yugoslavia. This tribunal was different from earlier ones in terms of its jurisdiction. The Tribunal consisted of two Trial Chambers and an Appeal Chamber, along with the Prosecutor and a Registry. Given the criticism of the previous trials about their political dependence, the Yugoslavia tribunal claimed to ensure the allocation of an independent prosecutor. 
Huzik, O., (2021)

The Genesis of the International Criminal Court

Finally, as the result of the trials, the ICTY has charged over 160 persons ranging from common soldiers to political, military, and police leaders. 21 were acquitted by the ICTY, while 90 persons were convicted and sentenced by the ICTY, also 13 cases were transferred to the national courts.

The lessons learned from the experience were important for the International Tribunal for the Prosecution of Persons Responsible for Genocide Committed in the Territory of Rwanda. The Rwanda tribunal was set up by the UN Security Council "on the strength" of the ICTY experience. During the situation in Rwanda rape, murder and genocide were widespread and required an urgent international settlement. To address this negative phenomenon, the Tribunal for the Prosecution of Persons Responsible for Genocide Committed in the Territory of Rwanda or Crimes Committed by Rwandans but in Neighboring Countries between 1 January 1994 and 31 December 1994 was established pursuant to a UN Security Council resolution of November 8, 1994, № 955. This tribunal was the first one in the categorization of sexual violence as a part of genocide.

The statutes of the Yugoslav and Rwandan tribunals defined the prosecutor's responsibilities in more detail than previous similar bodies. The ICTY's chief prosecutor responsible for investigating and prosecuting those responsible for serious violations of international humanitarian law has been appointed by the UN Security Council for a four-year term, is independent, and cannot seek or receive guidance from national governments. The prosecutor's discretion as to who is being prosecuted by the tribunal is mitigated by the fact that any proposed indictment must be approved by an ICTY judge. Similarly, the ICTR prosecutor "should not seek or receive instructions from any government or from any other source."

The main problem in the activities of these tribunals was the duration of their formation ( 2 years), in connection with which the issue of establishing a permanent international criminal court became more relevant.

There was also a Special Court for Sierra Leone established in 2002 by virtue of an agreement between the UN and Sierra Leone in accordance with the SC resolution 1315 (2000). It became the third ad hoc tribunal established by the UN Security Council. Interestingly, this was an example of so-called "hybrid courts", meaning that it has jurisdiction to prosecute individuals who violated both international humanitarian law and national law. Such "hybrid courts" have been also established in East Timor (2002) and Cambodia (2003).

All of these violent crimes happening around the world demonstrated the need for a permanent body through which the international community can react. This has led to intensified debates about the establishment of a permanent international court.

78 S sciendo Journal of Legal Studies Volume 28 Issue 42/2021

ISSN 2457-9017; Online ISSN 2392-7054.

Web: publicatii.uvvg.ro/index.php/jls. Pages $74-85$ 


\section{Features of the formation of the International Criminal Court}

Events of the XX century demonstrated the necessity of a permanent body with jurisdiction over international criminal cases. The draft ICC statute was completed by the ILC in 1994, after that it was submitted to the UN General Assembly. This was the point where the long but negotiations have started. The negotiations continued first through the Ad Hoc Committee meetings of 1995 and then at the sessions of the Preparatory Committee in 1996, 1997, and 1998. During that time, the draft has been significantly changed to be presented to the international community. For example, in the 1994 draft authors proposed that the ICC shall have the jurisdiction in certain conditions with regard to a range of "treaty crimes". Later this norm was found unacceptable and was changed in the final version of the statute. The Statute also largely complemented the principles of individual responsibility. It clearly identified cases in which an individual is the subject of an international crime and is, therefore, subject to the jurisdiction of the ICC.

In the summer of 1998, a special diplomatic conference - United Nations Conference of Plenipotentiaries on the Establishment of an International Criminal Court - was held in Rome to consider the consolidated text of the draft ICC Statute, hereinafter referred to as the Rome Statute. 163 countries were participants in those negotiations. It is worth mentioning, that as we described in the previous subsection a lot of ad hoc tribunals were at a place that time in many countries, which means representatives from those regions had particular expertise on issues of transitional justice and methods for ending the impunity that informed and strengthened ICC negotiations. Namely, ad hoc tribunals for former Yugoslavia and Rwanda began in 1993 and 1994, Special Court for Sierra Leone - in 2002, the hybrid court in Cambodia in 2003.

In addition to states' experience of combating gross human rights violations and bringing the perpetrators to justice, there were other events that informed positions of the states in Rome negotiations. As Benedetti et al. argue particularly significant and clearly reflected at the Rome Diplomatic Conference were the negotiations to create the Mine Ban Treaty and the Law of the Sea; the conferences on women's rights in Cairo, Stockholm, and Beijing; the perennial struggle about the status of the Palestinian territories.

The question of the ICC's jurisdiction, described by John Holmes, a Canadian delegate and adviser to Philippe Kirsch, as "the most complex and most sensitive" of the issues, divided the conference participants into two camps. The first one, socalled like-minded states, advocated for an effectively independent court. This group consisted of almost all states and supported the prosecutorial model of proprio motu. The second camp consisted of "R-5" with the exception of Great Britain. They disagreed with the idea of a proprio motu model of prosecution. The role of the UN 
Huzik, O., (2021)

The Genesis of the International Criminal Court

Security Council who could decide whether a case would be considered was particularly debatable, as it may lead to the politicization of the Court, as the first group argued.

Hot debates between the states were about the model of ICC jurisdiction: participants suggested options from universal jurisdiction to a jurisdiction triggered by the cumulative agreement of various states parties to the Statute. According to the draft Statute, the ICC should exercise its jurisdiction over the crime of genocide if a state party presented a complaint. However, many states have found it too narrow. The Republic of Korea put forward a new proposal providing for "automatic jurisdiction" in which the Court could exercise its jurisdiction when any of four possible states involved, namely, the territorial state, the states of the nationality of the accused and the victims, or the custodial state, had consented to ICC jurisdiction over the case by ratification or acceptance on an ad hoc basis. African states and like-minded states supported the automatic jurisdiction of the Korean proposal.

A diametrically opposite proposal came from the US and other permanent members of the Security Council. It was suggested that non-members of the Rome Statute should give their consent to the jurisdiction of the Court over a person accused of war crimes or crimes against humanity if the accused was a national of that State. Furthermore, it was offered to give a right to states parties to adopt an optional protocol to opt-out of the Court's jurisdiction for ten years, and this position would be renewable. Another proposal established an optional protocol allowing states parties to opt-out of the Court's jurisdiction for three years, and this position was not renewable.

All options remained open until the very last days of the Rome Diplomatic Conference, when the package deal presented by Philippe Kirsch - a Canadian lawyer and member of the Queen's Counsel who later became the 1st President of the International Criminal Court, was adopted. Kirsh`s proposal was upheld by a majority of participants, and the Court was crafted as an independent institution. It was accepted two preconditions to the Court's jurisdiction: first, the Court would have automatic jurisdiction following ratification by states parties or a positive declaration by non-states parties, and second, the Court could have jurisdiction over the crimes committed on the territory of a member state, or by a national of such state.

Other highly negotiated issues were: the adherence of the states to the International Law which is concerned about sovereignty disabled it from subjecting them to criminal law at a transnational level; the concept of international criminal responsibility4 definitions of crimes; death penalty; incorporation of crimes of sexual violence to the Statute; the concept of reparation to victims; broadened inclusion of victims` rights and interests. 
Nevertheless, the model of a stable International Criminal Court has received considerable, though not general, support. This shows the fact that the ICC Statute was adopted by a majority (120 - "for", 7 - "against", and 21 - "abstained"). Of the five permanent members of the UN Security Council who attended the conference, only two became parties to the Charter, Britain, and France, and the United States and China were among the seven countries that voted against the Charter. As for Russia, it, having signed the ICC Statute in 2000, was not among the full participants in this agreement, as it did not ratify it, and later withdrew its signature under this document.

The Rome Statute was adopted by 120 states very late at night on 17th July 1998 and was opened for signature. Ten delegations immediately signed it. The following day, twenty-six more states signed at an official ceremony. Yet, the Statute entered into force only on July 1, 2002, after its ratification by 60 countries.

During that four years, a lot of work has been done. The Preparatory Commission held five sessions of fourteen weeks in 1999 and 2000 at the UN Headquarters in New York to draft two critical documents that would determine how the Court would function. The commission was working on two main questions - the definitions of crimes and the proceedings as set up in the Statute.

Other questions were debated all around the world at international conferences. Namely, an international seminar on the issue of victims' access to the International Criminal Court hosted in Paris from 27 to 29 April 1999 was organized by the French government. The International Institute of Higher Studies in Criminal Sciences also hosted two intercessional meetings in Syracuse, Italy, in June 1999 and from January to February 2000. In order to facilitate the final adoption of the Rules of Procedure and Evidence, the Canadian government hosted an inter-sessional meeting of the coordinators and sub-coordinators in Mont-Tremblant from 30 April to 5 May in 2000. The Preparatory Commission to the ICC concluded its work on 6 June 2000.

To get the statute entered into force as early as possible, the Coalition for the International Criminal Court's Steering Committee, which was monitoring and contributing to the work of the Preparatory Commission, also focused on organizing a global signature and ratification campaign. First, it expanded to include more regional representation. International and national human rights organizations from developing countries were the main focus of the Committee. NGOs were particularly important as they became a link between the Committee and regional authorities. Today, the CICC has 2,500 NGOs as members, including regional and national coalitions in 150 countries.

Finally, on 11 March 2002, during the ninth session of the Preparatory Commission, ten states simultaneously ratified the Rome Statute and became the last ten countries out of 60, necessary for its entry into force, which happened on July 1, 2002. In August, the first session of the Assembly of States Parties to the Statute adopted two 
Huzik, O., (2021)

The Genesis of the International Criminal Court

main legal instruments of the ICC: Rules of Procedure and Proof and Elements of Crimes. The first 18 judges were elected in February 2003, and in April 2003 the Prosecutor (Luis Moreno-Ocampo of Argentina) was elected. The location of the International Criminal Court is The Hague (Netherlands).

\section{Conclusions}

The formation of the International Criminal Court lasted a long time and gradually. The study of events that took place since the end of the XIX century gives grounds to highlight the trends of international criminal justice and necessitates the selection of the following stages of its formation:

1) the end of the 19th century - before the First World War: characterized by the progress of the idea of the emergence of an international judicial body to resolve interstate conflicts; development of the concept of individual criminal liability for violation of humanitarian law;

2) The interwar period: the first attempts of the international community to bring to justice those who committed crimes during the First World War, the drafting of the first statute of the International Criminal Court, its discussion at an international conference; the emergence of the concept of crimes against humanity; growing interest in establishing an international criminal tribunal to combat international terrorism;

3) World War II - 2002: the activities of international tribunals as temporary bodies to bring to justice the criminals of the defeated parties; expanding the jurisdiction of international criminal law to domestic conflicts; expanding the jurisdiction of international tribunals for crimes of rape and conscription of minors; negotiations on the creation of an effective criminal court model;

4) 2002 - present - the period of introduction and functioning of the modern ICC as a permanent body.

Analysis of historical experience shows that one of the important prerequisites for the formation of the ICC was the lack of an effective mechanism for prosecuting crimes committed during the war. For example, as a result of the First World War, military courts organized by German national courts against their own citizens did not lead to a single conviction, which indicated the insufficiency of national criminal jurisdiction to prosecute international crimes. Acts that led to the genocide of entire nations also went unpunished. Moreover, the lack of an effective mechanism for dealing with such cases has led to the challenge and non-recognition of crimes committed for political reasons to date, which continues the secondary victimization of the victims of these crimes.

The practice of international tribunals has gained worldwide recognition and proved the effectiveness of the involvement of international bodies in the administration of justice in both external and internal armed conflicts. However, the interim authorities 
Huzik, O., (2021)

"Vasile Goldiș" Western University of Arad

The Genesis of the International Criminal Court

had many shortcomings, such as politicization, lack of adequate safeguards, subjectivity, the lengthy process of establishing tribunals, and inefficient use of funds. The experience of these international tribunals, and taking into account their shortcomings, was important in setting up a permanent judiciary. Such learning and mistakes led to complex but effective negotiations, and, as a result, the creation of an effective model of the ICC.

\section{Acknowledgments}

The author thanks the anonymous reviewers and editor for their valuable contribution.

\section{Funding}

This research received no specific grant from any funding agency in the public, commercial, or not - for - profit sectors.

\section{Author Contributions}

The entire article was written by Oleksandra Huzik.

\section{Disclosure Statement}

The author has not any competing financial, professional, or personal interests from other parties.

\section{References}

1. Andreasen, S. W., (2000). The International Criminal Court: does the Constitution preclude its ratification by the United States? Iowa Law Review, 85(2), 697-700.

2. Barnett L., (2013). The International Criminal Court: History and Role. Ottawa: Library of Parliament.

3. Bergsmo M., Cheah W. L., Song T., Yi P., (2015). Historical Origins of International Criminal Law, Volume 4. Brussels: Torkel Opsahl Academic EPublisher, 94 - 9.

4. Bogush G.I., Trikoz E. N., (2008). International Criminal Court: Problems, Discussions, Search for Solutions / Moscow: European Commission.

5. Bonneau, K., Washburn, J. L., Benedetti, F., (2014). Negotiating the international Criminal court: New York to Rome, 1994-1998. Brill.

6. Buromensky M.V., (2006). International Law: Textbook / Ed. - K .: Jurinkom Inter.

7. Çakmak Cenap. (2017). A brief history of international criminal law and international criminal court. Palgrave Macmillan.

8. Draft code of crimes against the peace and security of mankind [Electronic resource]. Access mode: http://law.edu.ru/norm/norm.asp?normID=1278896.

9. Holt\&Dallas, The Creation and Structure of the International Criminal Court https://www.jstor.org/stable/pdf/resrep1 1009.5.pdf?refreqid=excelsior\%3A04d2cd5ef9ef8e 1a92090cb1f525b598. 
Huzik, O., (2021)

10. Greppi, E., (19990. The Evolution of Individual Criminal Responsibility under International Law. Revue Internationale De La Croix-Rouge/International Review of the Red Cross, vol. 81, no. 835, 1999, pp. 531-553., doi:10.1017/S1560775500059782.

11. Kovalev, A.A., (2007). From Nuremberg to the International Criminal Court (problems of international criminal jurisdiction). Russian Yearbook of International Law. SPb.

12. Khamidova, M.F., (2017) Creation of the International Criminal Court and Legal Issues of Accountability for International Crimes. Bulletin of St. Petersburg State University. Right. T. 8. Iss. 2.

13. Legal Aid Cell DNLU. (n.d.). The genesis of international Criminal court: The journey From Nuremberg to The Hague. Vidhi Mitra. https://legalaiddnlu.wordpress.com/2020/08/29/the-genesis-of-international-criminal-courtthe-journey-from-nuremberg-to-the-hague/.

14. Marusin, I. S., (2004). International criminal justice institutions: the judiciary and the judiciary. $\mathrm{SPb}$.

15. Melissa, K. M., (1999). The International Criminal Court: Assessing the Jurisdictional Loopholes in the Rome Statute, 49 Duke Law Journal 825-853.

16. Polydorou, S., (2002). The Role of International Juridical Process in International Security and Civil-Military Relations: Master's Thesis / Naval Postgraduate School. Monterey.

17. Principles of International Law Recognized in the Charter of the Nürnberg Tribunal and in the Judgment of the Tribunal // Texts, instruments and final reports/International Law Commission.

URL:

https://legal.un.org/ilc/texts/instruments/english/draft_articles/7_1_1950.pdf.

18. Resolution 955 (1994), adopted by the Security Council at its 3453rd meeting on November 8, 1994. Database "Legislation of Ukraine" / The Verkhovna Rada of Ukraine. URL: https://zakon.rada.gov.ua/laws/show/995_d67.

19. The IV Convention on the Laws and Customs of War on Land and additions to it: Provisions on laws and conditions on land from 18.10.1907 // Database "Legislation of Ukraine" / Verkhovna Rada of Ukraine. URL: https://zakon.rada.gov.ua/laws/show/995_222\#Text. 20. The Versailles Treaty June 28, 1919 / Lillian Goldman Law Library. URL: https://avalon.law.yale.edu/subject_menus/versailles_menu.asp.

21. Tolochko, O. N., (2008). International criminal court: creation, activity, prospects / O. N. Tolochko // Justice of Belarus. 7 (78).

22. Shaw, M. N. (n.d.). Individual criminal responsibility in international law. International Law, 397-443. https://doi.org/10.1017/cbo9780511841637.009.

23. Statute of the International Tribunal for Rwanda of November 8, 1994 // Database "Legislation of Ukraine" / Verkhovna Rada of Ukraine. URL: https://zakon.rada.gov.ua/laws/show/995_d65\#Text.

84 Sciendo Journal of Legal Studies Volume 28 Issue 42/2021 
Huzik, O., (2021)

The Genesis of the International Criminal Court

24. Van Schaack, B., Slye, R. C., (2020). A concise history of international criminal law: Chapter 1 of international criminal law: Intersections \& contradictions. SSRN Electronic Journal. https://doi.org/10.2139/ssrn.1016152.

25. United Nations. International Tribunal for the Prosecution of Persons Responsible for Serious Violations of International Humanitarian Law Committed in the Territory of the Former Yugoslavia since 1991 IT/32/Rev.50 8 July 2015 Original: English \& French IT/32/Rev.50 8 July 2015 The Hague The Netherlands 8 July 2015 